\title{
Bakery waste in sheep diets: intake, digestibility, nitrogen balance and ruminal parameters ${ }^{1}$
}

\author{
Almira Biazon França ${ }^{2}$, Mirton José Frota Morenz ${ }^{3}$, Fernando César Ferraz Lopes ${ }^{3^{*}}$, Afranio \\ Silva Madeiro ${ }^{2}$, Danilo Antônio Morenz ${ }^{2}$, Bruna Moscat de Faria ${ }^{2}$, Luciano da Silva Cabral ${ }^{4}$, \\ Carlos Elysio Moreira da Fonseca ${ }^{5}$
}

\footnotetext{
${ }^{1}$ Research financed by FAPERJ.

2 Programa de Pós-Gradução em Zootecnia - UFRRJ.

${ }^{3}$ Embrapa Gado de Leite.

${ }^{4}$ Departamento de Zootecnia e Extensão Rural - UFMT.

5 Instituto de Zootecnia - UFRRJ.

* Researcher 2 from CNPq.
}

\begin{abstract}
The objective of the study was to evaluate the effects of bakery waste inclusion $(0 ; 25 ; 50 ; 75$ and $100 \%$, DM basis) in proportion to corn meal in the energetic mixture of the concentrate on intake, digestibility, nitrogen balance and ruminal parameters in sheep. Five male lambs with body weight of $30 \mathrm{~kg}$ were used in a $5 \times 5$ Latin square design. Experimental diets were composed of concentrate and Tifton 85 (Cynodon spp.) hay in a 60:40 forage:concentrate ratio. The concentrate rations were composed of corn meal, soybean meal and bakery waste. The bakery waste:corn meal ratio corresponded to the inclusion of, approximately, 0, 7, 14, 22 and 30\% (DM basis) of bakery waste in the diet. There was no effect of bakery waste inclusion on the intake and digestibility of nutrients, nor on nitrogen balance, $\mathrm{pH}$ values or concentrations of volatile fatty acids. However, the ammonia nitrogen concentration showed negative linear response in relation to the level of inclusion, in which each increase of $1 \%$ bakery waste promoted reduction of $0.11 \mathrm{mg} / \mathrm{dL}$ in the concentration of ammonia nitrogen. This fact may be related to the increase in ruminal availability of energy, which allows greater use of ammonia for microbial growth Bakery waste can replace corn meal in concentrate rations for sheep.
\end{abstract}

Key Words: ammonia, byproduct, lamb, pH, volatile fat acid

\section{Introduction}

The rise and instability of prices of protein and energetic concentrate feeds are important factors in animal production in order to allow the competitiveness of production systems. In this context, the purpose of using low-cost alternative feeds can be an appropriate strategy for increasing the sustainability of the animal production system.

Among the alternative foods, bakery waste stands out for its high concentration of non-fibrous carbohydrates, which are characterized as energetic food (Arosemena et al., 1995. Bakery waste is a potential substitute of corn in animal diets.

Bakery waste can be composed of cake leftovers, pieces of bread, biscuits, or non-marketed products that have exceeded the expiration date, besides the wastes due to breaking, excess or lack of cooking during processing (Wing, 1965).

Considerable amounts of bakery waste are available for use in animal feeding; however the use is limited due to the reduced number of evaluations of its nutritive value (Harris Junior \& Stapler, 1993). Studies have reported the existence of large differences in the chemical composition of the bakery waste used in animal feed (Champe \& Church, 1980; Dale, 1990; Arosemena et al., 1995; Saleh et al., 1996; Al-Tulaihan et al., 2004; Carneiro et al., 2006).

Therefore, this study aimed to evaluate the effects of the inclusion of bakery waste in sheep diet on feed intake, nutrient digestibility, nitrogen balance and ruminal parameters.

\section{Material and Methods}

The experiment was carried out at the Instituto de Zootecnia of the Universidade Federal Rural do Rio de Janeiro, Brazil, from October to December of 2008.

The bakery waste inclusion $(0 ; 25 ; 50 ; 75$ and $100 \%$ of dry mater) in proportion to corn meal in the energetic mixture of the concentrate was studied. Five crossbred male lambs, with average body weight of $30 \mathrm{~kg}$, distributed in a $5 \times 5$ Latin Square design were used. Each experimental period lasted 12 days, six days for adaptation to the experimental diets and the last ones for sampling.

Experimental animals were submitted to the preexperimental period (approximately, 30 days), for adaptation 
to the metabolism cage and concentrate and hay intake. During this period fecal samples of eggs per gram (EPG) were collected, applying the Gordon \& Whitlock modified technique (Ueno \& Gonçalves, 1998), and deworming when values above 700 EPG were observed.

Animals were kept in metabolism cages fitted with two aluminum feeders for supply of hay and concentrate separately, plastic bucket for water supply and a metal tray affixed on the bottom of each cage for urine collection. Total fecal collection was realized using collection bags adapted to each animal from the $7^{\text {th }}$ to the $12^{\text {th }}$ day of each period. Animals were managed twice daily (07:00 $\mathrm{h}$ and 17:00 h), when diets and cleanness of the cages was provided.

Experimental diets were constituted of concentrate and Tifton-85 grass hay (Cynodon spp.), using a 60:40 roughage:concentrate ratio. Water and mineral mixture were provided ad libitum. Concentrates rations were formulated to be isoproteic and meet the nutritional requirements of lambs, according to the category and body weight (NRC, 2007). At the beginning and end of each evaluation period, animals were weighed for the adjustment of diets.

The concentrate rations were formulated using corn meal, soybean meal and bakery waste (Table 1). The bakery waste inclusion in the energetic mixture of the concentrate was done in order to obtain a bakery waste:corn meal ratio of 0, 2550,75 and $100 \%$ (DM basis) (Table 2).

The bakery waste used in this experiment was weekly provided by Panco ${ }^{\circledR}$ bread factory, located in Seropédica $\mathrm{RJ}$, and constituted of bread in expired term, collected in supermarket and bakeries.

The bread was ground separately in electric grinding mills with 5-mm sieves of mesh size, to avoid ingredient selection by animals in the concentrate rations.

The total feces collection was performed twice daily (07:00 and 17:00 h) using collection bags, from the $7^{\text {th }}$ to $12^{\text {nd }}$ day in each experimental period. Immediately after collection, samples were placed in plastic bags properly identified, weighed and frozen at $-18^{\circ} \mathrm{C}$. In the same period, samples of diets and orts were collected in the morning $(07: 00 \mathrm{~h})$, for intake determination. At the end of each experimental period, fecal samples were unfrozen at room temperature for elaboration of composite samples. Fecal composite samples were elaborated by homogenizing all the samples obtained by the same animal in the period, and sampled a portion of, approximately, $500 \mathrm{~g} /$ animal/period. Immediately after this procedure, fecal samples were ovendried $\left(60 \pm 5^{\circ} \mathrm{C} ; 72 \mathrm{~h}\right)$. Afterwards, samples were ground to $2 \mathrm{~mm}$ through a Willey mil, packed in plastic bags and stored for further analysis.

Table 1 - Chemical composition of feeds used in experimental diets (DM basis)

\begin{tabular}{|c|c|c|c|c|c|c|c|}
\hline \multirow[t]{2}{*}{ Feed } & \multicolumn{7}{|c|}{ Chemical composition } \\
\hline & DM & OM & $\mathrm{CP}$ & EE & $\mathrm{NFC}^{1}$ & NDF & $\mathrm{TDN}^{2}$ \\
\hline Bakery waste $(\mathrm{g} / \mathrm{kg})$ & 69.89 & 96.89 & 13.65 & 3.22 & 78.88 & 2.12 & 89.35 \\
\hline Soybean meal $(\mathrm{g} / \mathrm{kg})$ & 87.57 & 93.62 & 53.01 & 1.21 & 23.31 & 13.72 & 83.66 \\
\hline Tifton-85 hay $(\mathrm{g} / \mathrm{kg})$ & 85.19 & 91.83 & 11.98 & 2.26 & 5.78 & 75.90 & 52.20 \\
\hline
\end{tabular}

Table 2 - Feed and chemical composition of experimental diets (DM basis)

\begin{tabular}{|c|c|c|c|c|c|}
\hline \multirow[t]{2}{*}{ Feed } & \multicolumn{5}{|c|}{ Bakery waste:corn meal ratio $(\%)^{1}$} \\
\hline & 0 & 25 & 50 & 75 & 100 \\
\hline Bakery waste $(\%)$ & - & 6.97 & 14.31 & 22.05 & 30.23 \\
\hline Soybean meal (\%) & 12.82 & 12.12 & 11.38 & 10.60 & 9.77 \\
\hline Tifton-85 hay (\%) & 60.00 & 60.00 & 60.00 & 60.00 & 60.00 \\
\hline Total & 100.00 & 100.00 & 100.00 & 100.00 & 100.00 \\
\hline Organic matter $(\mathrm{g} / \mathrm{kg})$ & 93.95 & 93.85 & 93.76 & 93.65 & 93.54 \\
\hline Crude protein $(\mathrm{g} / \mathrm{kg})$ & 16.52 & 16.51 & 16.49 & 16.48 & 16.46 \\
\hline Ether extract $(\mathrm{g} / \mathrm{kg})$ & 2.52 & 2.51 & 2.50 & 2.48 & 2.47 \\
\hline Neutral detergent fiber $(\mathrm{g} / \mathrm{kg})$ & 51.45 & 50.54 & 49.58 & 48.57 & 47.50 \\
\hline Non-fibrous carbohydrate $(\mathrm{g} / \mathrm{kg})^{2}$ & 26.78 & 27.43 & 28.12 & 28.85 & 29.61 \\
\hline Total digestible nutrients $(\mathrm{g} / \mathrm{kg})^{3}$ & 65.73 & 65.92 & 66.12 & 66.34 & 66.57 \\
\hline
\end{tabular}

${ }^{1} 0,25,50,75$ and 100: respectively, bakery waste:corn meal ratio in energetic mixture of the concentrate (DM basis).

2 Sniffen et al. (1992).

3 Weiss et al. (1992). 
The direct method was used for the determination of apparent digestibility of the nutrients, by evaluating the levels of nutrients in feed samples and feces. The apparent digestibility (AD) was obtained using the equation described by Coelho da Silva \& Leão (1979): AD = ((Nf - No - Nfc $) /$ $(\mathrm{Nf}-\mathrm{No}))^{*} 100$, where: $\mathrm{Nf}=$ nutrient in feed $(\mathrm{g}) ; \mathrm{No}=$ nutrient in orts $(\mathrm{g})$; and $\mathrm{Nfc}=$ nutrient in feces $(\mathrm{g})$.

Nitrogen balance was determined by collecting urine during 24 hours (Valadares et al., 1997), between the $11^{\text {th }}$ and $12^{\text {nd }}$ day in each experimental period. Urine was collected in plastic buckets fitted below the outlet of metal tray of each cage. Buckets were covered with screen to avoid contamination by hair, feces and ration. After the first urination, $100 \mathrm{~mL}$ of sulfuric acid (20\%) were added to each bucket, to avoid fermentation and ammonia loss by volatilization. At the end of the collection period, buckets were weighed and an aliquot of $5 \%$ of total urine output per animal was sampled, which were frozen $\left(-18^{\circ} \mathrm{C}\right)$ in glass bottles properly identified, for later determination of total nitrogen. Nitrogen balance was obtained by the difference between the total nitrogen intake and the total nitrogen excreted in feces and urine.

The rumen fluid was collected on the last day $\left(12^{\text {th }}\right.$ day) of each experimental period, three hours after morning feeding (Zeoula et al., 2003), with the aid of an esophageal silicone probe connected to a vacuum pump. Approximately $50 \mathrm{~mL}$ of rumen fluid were collected from each animal. The $\mathrm{pH}$ was measured immediately after collection, using the digital potentiometer (Tecnal ${ }^{\circledR}$, TEC $3 \mathrm{MP}$ ). Afterwards, samples were filtered through three layers of cheesecloth and two aliquots of $10 \mathrm{~mL}$ were taken from each one. Those were packed in pots containing eight drops of sulfuric acid $(50 \% \mathrm{~V} / \mathrm{V})$ for determination of ruminal ammonia concentration $\left(\mathrm{NH}_{3}-\mathrm{N}\right)$. Another aliquot was stored in pots containing $2 \mathrm{~mL}$ of metaphosphoric acid $(25 \% \mathrm{~W} / \mathrm{V})$ for determination of volatile fatty acids concentration. Both samples were stored at $-18^{\circ} \mathrm{C}$ for subsequent laboratory analysis.

$\mathrm{NH}_{3}-\mathrm{N}$ concentrations in rumen fluid samples were determined by distillation with potassium hydroxide (2N), according to technique described by Preston (1995).

The concentrations of the major volatile fatty acids (acetic, propionic and butyric) were determined using methods described by Wilson (1971), in which the samples, after being unfrozen at room temperature and centrifuged at $11000 \mathrm{G}$, were filtered in filter porosity of $45 \mu \mathrm{m}$ and stored in vials for the injection into a gas chromatograph (Agilent Technologies, model 6890N).

Samples of foods, orts and feces were analyzed for dry matter (DM) at $105^{\circ} \mathrm{C}$, crude protein $(\mathrm{CP})$, ether extract (EE), ash, neutral detergent fiber (NDF), acid detergent fiber (ADF), lignin (LIG) and cellulose (CEL), according to methods described by Silva \& Queiroz (2002).

The total digestible nutrients (TDN) contents of feedstuffs and diets were estimated according to the equation described by Weiss et al. (1992):

$\mathrm{TDN}(\%)=0.98 *(100-\mathrm{NDFn}-\mathrm{CP}-\mathrm{Ash})+\mathrm{EXP}$ $(-0.012 * \mathrm{ADIN}) * \mathrm{CP}+2.25 *(\mathrm{EE}-1)+0.75 *(\mathrm{NDFn}-\mathrm{Lig}) *(1-$ $\left.(\mathrm{Lig} / \mathrm{NDFn})^{0.667}\right)-7$,

where: EE is ether extract, assumed to be equal to total fat; ADIN is acid detergent insoluble nitrogen; Lig is Lignin (\% of NDF) and is computed as (Lignin /100)*NDF; NDFn is NDF corrected for nitrogen.

The TDN content of diets and its intake were calculated, after the digestibility assay, using the equation described by Sniffen et al. (1992):

$\mathrm{TDN}(\mathrm{g} / \mathrm{d})=\mathrm{DCP}+2.25 * \mathrm{DEE}+\mathrm{TDCH}$,

where: $\mathrm{DCP}=$ digestible crude protein; $\mathrm{DEE}=$ digestible ether extract; and TDCH = total digestible carbohydrates.

The digestible energy (DE) and metabolizable energy (ME) intake were calculated, according to NRC (2007), considering that $1 \mathrm{~kg}$ of NDT $=4.4 \mathrm{Mcal}$ of $\mathrm{DE}$, and that, approximately, $82 \%$ of DE is metabolizable $(\mathrm{ME}=0.82 * \mathrm{DE})$.

Data were submitted to normality test for distribution of errors and, subsequently, to analysis variance $(\alpha=0.05)$. Mean values were studied by regression analysis, using " $\mathrm{t}$ " test $(\alpha=0.05)$, applying the statistical package SISVAR (Ferreira, 2003).

\section{Results and Discussion}

There was no effect $(\mathrm{P}>0.05)$ of the bakery waste inclusion on dry matter and nutrients intakes, indicating that the palatability of the concentrate rations was not influenced by inclusion of the bakery waste (Table 3 ). Wallace (1965) suggested the use of bakery waste as ingredient of palatability in diets for calves and piglets.

Carneiro et al. (2006) evaluated the corn replacement by bakery waste in sheep diets and also did not observe effect on dry matter intake, using the replacement levels of $20,40,60$ and $80 \%$.

There is a wide variation in the literature about the chemical composition of bakery waste, mainly in relation to the EE values. Such variation makes it difficult to compare these values to those obtained by other authors. This variation is attributed to the diversity of ingredients that can compose the bakery waste (bread, cakes, cookies, flour, among others), their origin (factory, region), the storing and the processing before the use in animal nutrition. 
Champe \& Church (1980), studying the use of bakery waste in sheep diet, reported values of 8.5 and $10.4 \%$ for $\mathrm{CP}$ and EE contents, respectively. Other authors, such as Dale (1990), Saleh et al. (1996), Al-Tulaihan et al. (2004) and Carneiro et al. 2006 obtained values of 11.1, 11.0, 1.32 and $17.7 \%$ for EE, and 10.6, 12.5, 12.2, 9.9\% for CP, respectively.

Arosemena et al. (1995) evaluated the chemical composition of bakery waste from different origins and observed variations of 4.46 to $11.70 \%$ in EE contents, and from 11.9 to $13.3 \%$ in $\mathrm{CP}$ contents.

The TDN intake was not affected $(\mathrm{P}>0.05)$ by the bakery waste:corn meal ratio, although the TDN content of the bakery waste used in this study was slightly higher than the values obtained for the corn meal.

Therefore, although the experimental diets were not formulated to be isoenergetic, the bakery waste inclusion in diet did not influence $(\mathrm{P}>0.05)$ the $\mathrm{DE}$ or ME intakes, showing that the use of bakery waste did not alter the amount of energy available in the diet for the animals, since ME is the energy currently available for animal metabolism.

The apparent digestibility of the nutrients was not influenced $(\mathrm{P}>0.05)$ by bakery waste:corn meal ratio (Table 4).
Champe \& Church (1980) evaluated the digestibility of diets with 0,20 and $40 \%$ of corn replacement by bakery waste, and observed an increase in DM apparent digestibility with the waste inclusion, reporting values of $68.3,73.5$ and $78.3 \%$ for the three replacement levels, respectively, which are higher than those observed in this study. However, Carneiro et al. (2006) also found no effect in replacing up to $80 \%$ of the corn by bakery waste on DM apparent digestibility in sheep, with similar value to that obtained in this study, $59.0 \%$.

Carneiro et al. (2006), using bakery waste with $17.7 \%$ $\mathrm{EE}$ in sheep diets, observed value for the digestibility of EE greater than the present study, 51.2\%. Champe \& Church (1980) observed a significant increase in EE digestibility with the bakery waste inclusion, with values of $19.4,60.0$ and $73.2 \%$, with the inclusion of 0,20 and $40 \%$, respectively.

The TDN content of the bakery waste used in this study was higher than that obtained for corn meal, which provided a slight increase in TDN content in diets with the increase of bakery waste inclusion in the energetic mixture of the concentrate (Table 2). However, no effect was observed $(\mathrm{P}>0.05)$ in the TDN contents of the diets. Waller (2010)

Table 3 - Daily nutrients intake in sheep fed diets containing bakery waste

\begin{tabular}{|c|c|c|c|c|c|c|c|}
\hline \multirow[t]{2}{*}{ Variable } & \multicolumn{5}{|c|}{ Bakery waste:corn meal ratio $(\%)^{1}$} & \multirow[t]{2}{*}{ Mean } & \multirow[t]{2}{*}{$\mathrm{CV}(\%)$} \\
\hline & 0 & 25 & 50 & 75 & 100 & & \\
\hline DM (g/day) & 793.95 & 813.08 & 828.71 & 802.84 & 798.67 & 807.55 & 4.73 \\
\hline DM (g/kg BW) & 2.67 & 2.66 & 2.77 & 2.68 & 2.70 & 2.70 & 7.98 \\
\hline DM $\left(g / \mathrm{kg}^{0.75}\right)$ & 62.14 & 62.42 & 64.80 & 62.36 & 62.83 & 62.91 & 7.23 \\
\hline OM (g/day) & 746.98 & 779.86 & 810.33 & 804.85 & 816.51 & 791.71 & 9.02 \\
\hline CP (g/day) & 133.39 & 138.86 & 144.45 & 145.48 & 146.50 & 141.74 & 9.46 \\
\hline EE (g/day) & 20.16 & 20.97 & 21.63 & 21.47 & 21.61 & 21.17 & 5.93 \\
\hline NDF (g/day) & 396.01 & 408.74 & 417.05 & 392.42 & 396.18 & 402.08 & 10.13 \\
\hline NDF (g/kg BW) & 1.33 & 1.34 & 1.40 & 1.30 & 1.34 & 1.34 & 7.79 \\
\hline TDN (g/day $)^{2}$ & 438.56 & 478.16 & 486.51 & 483.30 & 468.12 & 470.93 & 12.81 \\
\hline $\mathrm{DE}(\mathrm{Mcal} / \mathrm{g} \mathrm{DM})^{3}$ & 1.93 & 2.10 & 2.14 & 2.13 & 2.06 & 2.07 & 12.82 \\
\hline $\operatorname{ME}(\mathrm{Mcal} / \mathrm{g} \mathrm{DM})^{3}$ & 1.58 & 1.73 & 1.76 & 1.74 & 1.70 & 1.70 & 12.82 \\
\hline
\end{tabular}

$\mathrm{DM}=$ dry matter; $\mathrm{OM}=$ organic matter; $\mathrm{CP}=$ crude protein; $\mathrm{EE}=$ ether extract; $\mathrm{NDF}=$ neutral detergent fiber; $\mathrm{TDN}=$ total digestible nutrients; $\mathrm{DE}=$ digestible energy; $\mathrm{ME}=$ metabolizable energy $\mathrm{CV}=$ coefficient of variation

${ }_{1}^{1} 0,25,50,75$ and 100: respectively, bakery waste:corn meal ratio in energetic mixture of the concentrate (DM basis).

2 Sniffen et al. (1992).

${ }^{3}$ NRC (2007).

Table 4 - Apparent digestibility of nutrients and TDN contents of diets containing bakery waste

\begin{tabular}{|c|c|c|c|c|c|c|c|}
\hline \multirow[t]{2}{*}{ Variable } & \multicolumn{5}{|c|}{ Bakery waste:corn meal ratio $(\%)^{1}$} & \multirow[t]{2}{*}{ Mean } & \multirow[t]{2}{*}{$\mathrm{CV}(\%)$} \\
\hline & 0 & 25 & 50 & 75 & 100 & & \\
\hline DM (g/g) & 55.60 & 59.83 & 58.64 & 58.45 & 56.65 & 57.83 & 7.60 \\
\hline OM $(\mathrm{g} / \mathrm{g})$ & 56.44 & 61.12 & 60.78 & 61.77 & 60.62 & 60.15 & 6.80 \\
\hline $\mathrm{CP}(\mathrm{g} / \mathrm{g})$ & 64.79 & 68.00 & 68.38 & 69.65 & 69.19 & 68.00 & 4.55 \\
\hline $\mathrm{EE}(\mathrm{g} / \mathrm{g})$ & 66.30 & 70.63 & 68.17 & 69.84 & 66.49 & 68.19 & 5.54 \\
\hline NDF (g/g) & 40.72 & 46.74 & 44.59 & 42.10 & 41.19 & 43.07 & 16.24 \\
\hline TDN $(\mathrm{g} / \mathrm{kg})^{2}$ & 54.51 & 59.01 & 58.58 & 59.48 & 58.30 & 57.98 & 6.78 \\
\hline
\end{tabular}

$\mathrm{DM}=$ dry matter; $\mathrm{OM}=$ organic matter; $\mathrm{CP}=$ crude protein; $\mathrm{EE}=$ ether extract; $\mathrm{NDF}=$ neutral detergent fiber; $\mathrm{TDN}=$ total digestible nutrients; $\mathrm{CV}=$ coefficient of variation

${ }_{1}^{1} 0,25,50,75$ and 100: respectively, bakery waste:corn meal ratio in energetic mixture of the concentrate (DM basis).

2 Sniffen et al. (1992). 
described TDN value for bakery waste similar to that observed in this study, $89.0 \%$.

Nitrogen intake was not influenced $(\mathrm{P}>0.05)$ by the bakery waste:corn meal ratio (Table 5).

Excretion of urinary and fecal nitrogen and nitrogen balance were not influenced $(\mathrm{P}>0.05)$ by inclusion of bakery waste in the diet. However, the $\mathrm{N}$ excretion in feces was higher than in urine. According to Van Soest (1994), the increase in $\mathrm{N}$ intake is associated with the increase of the urea production in the liver and, consequently, of its excretion in urine, while the low $\mathrm{N}$ intake leads to a reduction in the excretion of urea in urine for maintenance of the pool of urea in the plasma, which is under homeostatic physiological control.

The inclusion of bakery waste in concentrate had no effect $(\mathrm{P}>0.05)$ on $\mathrm{pH}$ or ruminal volatile fatty acids concentration. However, a decrease $(\mathrm{P}<0.05)$ in ruminal ammonia nitrogen $\left(\mathrm{NH}_{3}-\mathrm{N}\right)$ concentrations with the increase in inclusion levels of bakery waste in the energetic mixture of the concentrate was observed (Table 6).
According to Smith et al. (1972), variations between 6.0 and 6.8 in ruminal $\mathrm{pH}$ provide maximum activity of cellulolytic organisms. Therefore, the inclusion of bakery waste in diet did not affect the rate of microbial growth negatively.

There was a negative linear response $(\mathrm{P}<0.05)$ of the ruminal $\mathrm{NH}_{3}-\mathrm{N}$ concentration with the increase in bakery waste levels, where each $1 \%$ of bakery waste inclusion promoted reduction of $0.11 \mathrm{mg} / \mathrm{dL}$ in ruminal $\mathrm{NH}_{3}-\mathrm{N}$ concentration.

This reduction in ruminal $\mathrm{NH}_{3}-\mathrm{N}$ concentration may be related to the increase in energy availability for microbial protein synthesis, provided by the bakery waste inclusion in the diet; or associated to the lower inclusion of soybean meal in diets due to the higher CP content in the waste when compared with the corn meal. The lower inclusion of soybean meal in the diets could reduce the $\mathrm{NH}_{3}-\mathrm{N}$ availability for microbial protein synthesis due to the fact that the soybean meal protein has intermediate ruminal degradation (Cabral et al., 2000).

Table 5 - Intake, excretion and nitrogen balance of lambs fed diets with bakery waste

\begin{tabular}{|c|c|c|c|c|c|c|c|}
\hline \multirow[t]{2}{*}{ Variable } & \multicolumn{5}{|c|}{ Bakery waste:corn meal ratio $(\%)^{1}$} & \multirow[t]{2}{*}{ Mean } & \multirow[t]{2}{*}{ CV (\%) } \\
\hline & 0 & 25 & 50 & 75 & 100 & & \\
\hline $\begin{array}{l}\mathrm{N} \text { intake } \\
\mathrm{g} / \text { day } \\
\mathrm{g} / \mathrm{kg}^{0.75}\end{array}$ & $\begin{array}{c}21.34 \\
1.67\end{array}$ & $\begin{array}{c}22.22 \\
1.71\end{array}$ & $\begin{array}{c}23.11 \\
1.81\end{array}$ & $\begin{array}{c}23.28 \\
1.82\end{array}$ & $\begin{array}{c}23.44 \\
1.85\end{array}$ & $\begin{array}{c}22.68 \\
1.77\end{array}$ & $\begin{array}{l}9.46 \\
8.13\end{array}$ \\
\hline $\begin{array}{l}\mathrm{N} \text { fecal } \\
\mathrm{g} / \text { day } \\
\mathrm{g} / \mathrm{kg}^{0.75} \\
\% \mathrm{NCI}\end{array}$ & $\begin{array}{c}7.48 \\
0.59 \\
35.21\end{array}$ & $\begin{array}{c}7.11 \\
0.54 \\
32.00\end{array}$ & $\begin{array}{c}7.32 \\
0.57 \\
31.62\end{array}$ & $\begin{array}{c}6.96 \\
0.55 \\
30.35\end{array}$ & $\begin{array}{c}7.16 \\
0.56 \\
30.81\end{array}$ & $\begin{array}{c}7.20 \\
0.56 \\
31.99\end{array}$ & $\begin{array}{c}8.96 \\
10.69 \\
10.68\end{array}$ \\
\hline $\begin{array}{l}\mathrm{N} \text { urine } \\
(\mathrm{g} / \text { day }) \\
\mathrm{g} / \mathrm{kg}^{0.75} \\
\% \mathrm{NI}\end{array}$ & $\begin{array}{c}5.82 \\
0.47 \\
28.63\end{array}$ & $\begin{array}{c}6.90 \\
0.52 \\
30.04\end{array}$ & $\begin{array}{c}6.71 \\
0.53 \\
29.29\end{array}$ & $\begin{array}{c}6.97 \\
0.53 \\
29.35\end{array}$ & $\begin{array}{c}5.93 \\
0.47 \\
25.12\end{array}$ & $\begin{array}{c}6.47 \\
0.51 \\
28.49\end{array}$ & $\begin{array}{l}18.89 \\
16.51 \\
16.06\end{array}$ \\
\hline $\begin{array}{l}\mathrm{NB} \\
\mathrm{g} / \mathrm{day} \\
\mathrm{g} / \mathrm{kg}^{0.75} \\
\% \mathrm{NI}\end{array}$ & $\begin{array}{c}8.05 \\
0.62 \\
36.16 \\
\end{array}$ & $\begin{array}{c}8.21 \\
0.64 \\
37.96 \\
\end{array}$ & $\begin{array}{c}9.08 \\
0.70 \\
39.10 \\
\end{array}$ & $\begin{array}{c}9.34 \\
0.73 \\
40.30 \\
\end{array}$ & $\begin{array}{c}10.36 \\
0.81 \\
44.06 \\
\end{array}$ & $\begin{array}{c}9.00 \\
0.70 \\
39.52 \\
\end{array}$ & $\begin{array}{l}15.64 \\
16.01 \\
12.36 \\
\end{array}$ \\
\hline
\end{tabular}

${ }^{1} 0,25,50,75$ and 100: respectively, bakery waste:corn meal ratio in energetic mixture of the concentrate (DM basis).

$\mathrm{N}=$ nitrogen; $\mathrm{NI}=$ nitrogen intake; $\mathrm{NB}=$ nitrogen balance; $\mathrm{CV}=$ coefficient of variation.

Table 6 - Ruminal parameters of lambs fed diets counting bakery waste

\begin{tabular}{|c|c|c|c|c|c|c|c|}
\hline \multirow[t]{2}{*}{ Variable } & \multicolumn{5}{|c|}{ Bakery waste:corn meal ratio $(\%)^{1}$} & \multirow[t]{2}{*}{ Mean } & \multirow[t]{2}{*}{ CV $(\%)$} \\
\hline & 0 & 25 & 50 & 75 & 100 & & \\
\hline $\mathrm{pH}$ & 6.90 & 6.95 & 6.71 & 7.05 & 6.92 & 6.90 & 3.13 \\
\hline VFA $(\mu \mathrm{MOL} / \mathrm{mL})$ & 44.08 & 43.93 & 45.84 & 45.58 & 37.92 & 43.47 & 20.70 \\
\hline $\mathrm{Ac}(\mu \mathrm{MOL} / \mathrm{mL})$ & 33.61 & 33.53 & 34.08 & 33.57 & 27.77 & 32.51 & 20.55 \\
\hline $\operatorname{Pr}(\mu \mathrm{MOL} / \mathrm{mL})$ & 7.14 & 6.95 & 7.62 & 7.72 & 6.46 & 7.18 & 20.03 \\
\hline $\mathrm{Bu}(\mu \mathrm{MOL} / \mathrm{mL})$ & 3.33 & 3.45 & 4.41 & 4.28 & 3.69 & 3.78 & 33.39 \\
\hline
\end{tabular}


It is noteworthy that the reduction in the ruminal $\mathrm{NH}_{3}-\mathrm{N}$ concentrations can be a positive factor, since it does not compromise the efficiency of microbial synthesis, given that excess in $\mathrm{NH}_{3}-\mathrm{N}$ in the rumen promotes reduction in the energetic efficiency of the diet, because of the energetic cost of its conversion into urea in the liver.

According to Carvalho et al. (1997), the reduction in ruminal $\mathrm{NH}_{3}-\mathrm{N}$ concentration can be explained by the increase in energy availability in the rumen, allowing higher use of ammonia for microbial growth, with consequent reduction in ammonia loss due to synchronization in the carbohydrates and protein degradation.

However, Mehrez et al. (1977) stated that the maximum activity of rumen fermentation is obtained when the $\mathrm{NH}_{3}-\mathrm{N}$ concentration reaches values between 19 and $23 \mathrm{mg} / \mathrm{dL}$ in the rumen fluid. Van Soest (1994) reported the optimal level of $10 \mathrm{mg} / \mathrm{dL}$, a value close to the concentration of $\mathrm{NH}_{3}-\mathrm{N}$ obtained with the proportion of $100 \%$ of bakery waste. However, this should not be considered a fixed number, considering that the ability of bacteria to use ammonia and to synthesize protein depends on the fermentation of carbohydrates rate.

The molar ratios of acetate:propionate:butyrate produced in the rumen of sheep fed diets with bakery waste:corn meal ratios of $0,25,50,75$ and $100 \%$, were 77:16:7; 76:16:8,74:17:9, 74:17:9 and 73:17:10, respectively.

The volatile fatty acids are the main energy source for ruminants, supplying up to $80 \%$ of the daily requirements (Kononoff \& Varga, 1999). Therefore, changes in the olatile fatty acids profile can affect the energetic partition and animal performance.

\section{Conclusions}

Bakery waste can be included in sheep diets without altering intake, nutrient digestibility, nitrogen balance, ruminal $\mathrm{pH}$ or concentration of volatile fatty acids, promoting greater ammonia nitrogen utilization by ruminal microorganisms.

\section{Acknowledgements}

To CAPES, for grating the scholarship to Almira Biazon França.

\section{References}

AL-TULAIHAN, A.A.; NAJIB, H.; AL-EID, S.M. The nutritional evaluation of locally produced dried bakery waste (DBW) in the broiler diets. Pakistan Journal of Nutrition, v.3, n.5, p.294-299, 2004.
AROSEMENA, A.; DePETERS, E.J.; FADEL, J.G. Extent of variability in nutrient composition within selected byproduct feedstuffs. Animal Feed Science and Technology, v.54, p.103-120, 1995 .

CABRAL, L.S.; FILHO, S.C.V.; MALAFAIA, P.A.M. et al. Frações protéicas de alimentos tropicais e sua taxas de digestão estimada pela incubação com proteases ruminais. Revista Brasileira de Zootecnia, v.26, n.6, p.2316-2324, 2000.

CARNEIRO, M.S.S.; OLIVEIRA, A.H.; SALES, R.O. et al. Valor nutritivo de rações para ovinos com quatro níveis do resíduo de panificação. In: REUNIÃO ANUAL DA SOCIEDADE BRASILEIRA DE ZOOTECNIA, 43., 2006, João Pessoa. Anais... João Pessoa: Sociedade Brasileira de Zootecnia, 2006. p.1-3.

CARVALHO, A.U.; VALADARES FILHO, S.C.; COELHO DA SILVA, J.F. et al. Níveis de concentrados em dietas de zebuínos. 4. Concentrações ruminais de amônia e pH, taxa de passagem de digesta ruminal e degradação in situ dos alimentos. Revista Brasileira de Zootecnia, v.26, n.5, p.1016-1024, 1997.

CHAMPE, K.A.; CHURCH, D.C. Digestibility of dried bakery product by sheep. Journal of Animal Science, v.51, n.1, p.25-27, 1980 .

COELHO DA SILVA, J.F., LEÃO, M.I. Fundamentos de nutrição dos ruminantes. Piracicaba: Editora Livroceres, 1979. 380p.

DALE, N.M. Energy and nutrient content of dried bakery product and crab meal. Poultry Science, v.65, p.163, 1990 (supl.1).

FERREIRA, D.F. Sistema de análise de variância - SISVAR DEX/UFLA, ver 4.3 (Build 45), 1999 - 2003.

HARRIS JUNIOR, B.; STAPLER, C.R. Feeding by-product feedstuffs to dairy cattle. Gainesville: University of Florida, Dairy Science Department, 1993. p.1-6.

KONONOFF, P.; VARGA, G.A. Dairy ration using structural and nonstructural carbohydrates: from theory to practice In: SOUTHWEST NUTRITION AND MANAGEMENT CONFRENCE, 1999, Arizona. Proccedings... Arisona: University of Arisona, 1999. p.77-90.

MEHREZ, A.Z.; ØRSKOV, E.R.; McDONALD, I. Rates of rumen fermentation in relation to ammonia concentration. British Journal Nutrition, v.38, n.3, p.437-443, 1977.

NATIONAL RESEARCH COUNCIL - NRC. Nutrient requirements of small ruminants: sheep, goats, cervids, and new world camelids. Washington, D.C.: 2007. 362p

PRESTON, T.R. Biological and chemical analytical methods. In PRESTON, T.R. (Ed.) Tropical animal feeding: a manual for research workers. Rome: FAO, 1995. p.191-264.

SALEH, E.A.; WATKINS, S.E.; WALDROUP, P.W. High- level usage of dried bakery product in broiler diets. Journal Applied Poultry Science, v.5, p.33-38, 1996

SILVA, D.J.; QUEIROZ, A.C. Análise de alimentos: métodos químicos e biológicos. 3.ed. Viçosa, MG: Editora UFV, 2002. 235p.

SMITH, L.W.; GOERING, M.K.; GORDON, C.H. Relationship of forage compositions with rates of cell wall digestion and indigestibility of cell walls. Journal of Dairy Science, v. 55 , n. 8, p.1140-1148, 1972 .

SNIFFEN, C.J.; O'CONNOR, J.D.; VAN SOEST, P.J. et al. A net carbohydrate and protein system for evaluating cattle diets: II. Carbohydrate and protein availability. Journal of Animal Science, v.70, p.3562-3577, 1992.

UENO, H.; GONÇALVES, P.C. Manual para diagnóstico das helmintoses de ruminantes. 4.ed. Tokyo: Japan International Cooperation Agency, 1998. 166p.

VALADARES, R.F.D.; GONÇALVES, L.C.; RODRIGUEZ, N.M. et al. Metodologia de coleta de urina em vacas utilizando sondas de Folley. Revista Brasileira de Zootecnia, v.26, n.6, p.1279-1282, 1997.

Van SOEST, P.J. Nutrition ecology of the ruminant. Ithaca: Comstock Publishing Associates, 1994. p.476.

WALLACE, H.D. Dried bakery product as a feed for swine Feedstuffs, v.37, n.25, p.52-53, 1965. 
WALLER, J.C. Byproducts and unusual feedstuffs. Feedstuffs, v.82, n. 38, p. 18-23, 2010.

WEISS, W.P.; CONRAD, H.R.; PIERRE, N.R.S. A theoreticallybased model for predicting total digestible nutrient values of forages and concentrates. Animal Feed Science Technology, v.39, p.95-110, 1992

WILSON, R.K. A rapid accurate method for measuring volatile fatty acids lactic acid in silage. Research Report. Dublin, Ireland: Agricultural Institute Dunsinea Research Centre, 1971. 7p.
WING, J.M. Preliminary evaluation of dried bakery product in dairy cattle rations. Feedstuffs, v.37, n.19, p.128, 1965.

ZEOUlA, L.M.; CALDAS NETO, S.F.; GERON, L.J.V. et al. Substituição do milho pela farinha de varredura de mandioca (Manihot esculent, Crantz) em rações de ovinos: consumo, digestibilidade, balanços de nitrogênio e energia e parâmetros ruminais. Revista Brasileira de Zootecnia, v.32, n.2, p.491-502, 2003 . 